\title{
(+)-Bornyl Piperate, a New Monoterpene Ester from Piper aff. pedicellatum Roots
}

\author{
Thitima Rukachaisirikul, ${ }^{*}, a$ Samran Prabpai, ${ }^{a}$ Palangpon Kongsaeree, ${ }^{b}$ and Apichart Suksamrarn ${ }^{a}$ \\ ${ }^{a}$ Department of Chemistry, Faculty of Science, Ramkhamhaeng University; Bangkok, Thailand: and ${ }^{b}$ Department of \\ Chemistry, Faculty of Science, Mahidol University; Bangkok, Thailand. \\ Received December 11, 2003; accepted January 30, 2004
}

\begin{abstract}
A new monoterpene ester, (+)-bornyl piperate was isolated from the underground roots of Piper aff. pedicellatum and its structure was elucidated on the basis of spectroscopic evidence and confirmed by $\mathrm{X}$-ray analysis. The compound crystallizes in the triclinic space group $P 1$ with $a=7.3232(4) \AA, b=11.4705(7) \AA, c=23.2520(14) \AA$, $V=1943.6(2) \AA^{3}$. This compound showed an antituberculosis activity against Mycobacterium tuberculosis $\left(\mathrm{H}_{37} \mathrm{Ra}\right.$ strain) with the minimum inhibitor concentration (MIC) of $25 \mu \mathrm{g} / \mathrm{ml}$.
\end{abstract}

Key words Piper aff. pedicellatum; Piperaceae; antituberculosis; Mycobacterium tuberculosis

Piper aff. pedicellatum C. DC. (Piperaceae) is distributed mainly in Northern Thailand. Its roots and stems are used as a carminative in Thai folk medicine. Although there are many reports on the phytochemistry of the genus Piper, ${ }^{1)}$ no previous record on the chemical constituents of this plant species has been found in the literature. As part of our ongoing project on bioactive compounds from Thai medicinal plants for the treatment of tropical diseases, we have investigated this plant species. We now describe the isolation and structure elucidation of a new monoterpene ester, (+)-bornyl piperate (1) together with eight known compounds (2-9) from the hexane and the methanol extracts of the underground roots of $P$. aff. pedicellatum.

The powdered roots of $P$. aff. pedicellatum were extracted successively with $n$-hexane and $\mathrm{MeOH}$ in a Soxhlet apparatus. The hexane extract on chromatography over silica gel gave one new compound (1) and six known compounds (2 7), while chromatography of the methanol extract afforded two more known compounds $(\mathbf{8}-\mathbf{9})$. The known compounds were identified as a mixture of $\beta$-sitosterol (2) 2 and stigmasterol $(3),{ }^{2)}$ pellitorine (4), ${ }^{3)}$ guineensine $(5),{ }^{4)}$ pipernonaline $(6),{ }^{5)}$ piperine $(7)^{6)}$ and a mixture of $\beta$-sitosteryl-3- $O$ - $\beta$-glu-

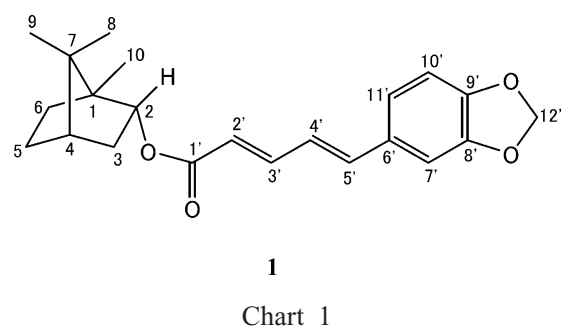

copyranoside $(\mathbf{8})^{7}$ and stigmasteryl-3-O- $\beta$-glucopyranoside $(9)^{8)}$ by comparison of their physical and spectroscopic data with those reported in the literature.

Compound 1 was obtained as colorless needles and its molecular formula was determined to be $\mathrm{C}_{22} \mathrm{H}_{26} \mathrm{O}_{4}$ by HRFAB-MS $\left(m / z ~ 355.1905,[\mathrm{M}+\mathrm{H}]^{+}\right)$. Its IR spectrum displayed an absorption band at $1710 \mathrm{~cm}^{-1}$, indicating the presence of a conjugated ester group. The ${ }^{1} \mathrm{H}$ - and ${ }^{13} \mathrm{C}$-NMR spectra exhibited the presence of the $2 E, 4 E$-piperoyl moiety. ${ }^{6}$ The remaining ${ }^{1} \mathrm{H}$ - and ${ }^{13} \mathrm{C}-\mathrm{NMR}$ signals of $\mathbf{1}$ were very similar to those reported for the bornyl group of bornyl $p$ coumarate isolated from $P$. ribesioides. ${ }^{9}$ In the HMBC spectrum, a long range correlation was observed between the piperoyl carbonyl carbon $\mathrm{C}-1^{\prime}(\delta 167.5)$ and the $\mathrm{H}-2$ proton ( $\delta$ 4.96) of the bornyl moiety. The stereochemistry at C-2 was determined by means of a NOE experiment. Upon irradiation of $\mathrm{H}-2$, a NOE enhancement was observed for $\mathrm{H}-3 \beta$, $8-\mathrm{CH}_{3}$ and $10-\mathrm{CH}_{3}$, showing that the piperoyl group is located at the endo side of the bornyl moiety. Moreover, the Xray structure (Fig. 1) confirmed the relative stereochemistry of $\mathbf{1}$. It should be noted that the X-ray crystal structure of (+)-bornyl $p$-coumarate isolated from $P$. caninum $^{10)}$ has recently been established. Therefore, the structure of 1 was established as 2-endo-bornyl piperate.

Compound 1 exhibited an antituberculosis activity against Mycobacterium tuberculosis $\left(\mathrm{H}_{37} \mathrm{Ra} \text { strain }\right)^{11)}$ with the MIC of $25 \mu \mathrm{g} / \mathrm{ml}$.

\section{Experimental \\ General Procedures Melting points were determined on an Electrother- mal apparatus and are uncorrected. UV spectra were measured with a Perkin} Elmer Lamda 20 spectrophotometer. IR spectra were obtained with a Perkin

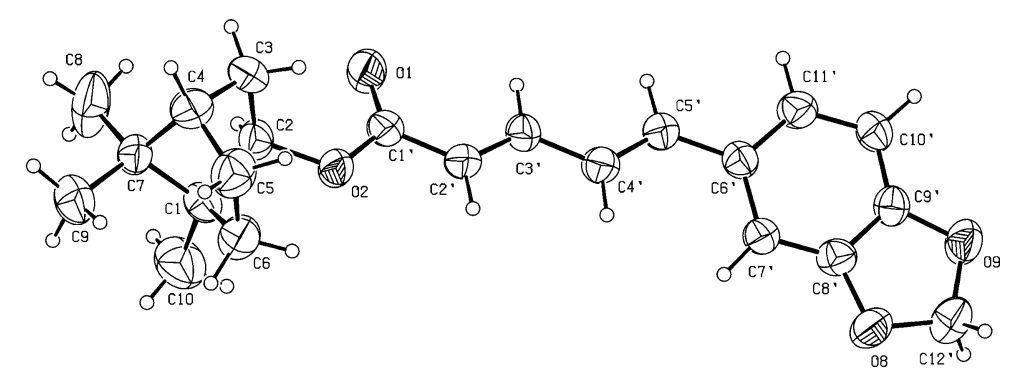

Fig. 1. ORTEP Perspective Drawing of 1 
Elmer Spectrum 2000 spectrophotometer. ${ }^{1} \mathrm{H}$ - and ${ }^{13} \mathrm{C}-\mathrm{NMR}$ spectra were recorded on a Bruker AVANCE 400 NMR spectrometer, operating at 400 and $100 \mathrm{MHz}$, respectively. Mass spectra were recorded with a Finnigan MAT 90 instrument. Column chromatography and TLC were carried out using Merck silica gel $60\left(>230\right.$ mesh) and precoated silica gel $60 \mathrm{~F}_{254}$ plates, respectively. Spots on TLC were visualized under UV light and by spraying with anisaldehyde- $\mathrm{H}_{2} \mathrm{SO}_{4}$ reagent followed by heating.

Plant Material The underground roots of $P$. aff. pedicellatum were collected from Pasang district, Lamphun province, Thailand in December, 1999. A voucher specimen (No. BKF 93307) has been deposited at the herbarium of the Royal Forest Department, Ministry of Agriculture and Cooperatives, Bangkok.

Extraction and Isolation The air-dried, powdered roots of $P$. aff. pedicellatum $(314.5 \mathrm{~g})$ were extracted successively with $n$-hexane and $\mathrm{MeOH}$ using a Soxhlet apparatus. The hexane and $\mathrm{MeOH}$ extracts were evaporated to dryness in vacuo. The hexane extract $(7.44 \mathrm{~g})$ was subjected to a silica gel column $(150 \mathrm{~g})$ using a gradient solvent system of hexane, hexane-EtOAc and EtOAc (5\% increment of the polar solvent for each $250 \mathrm{ml}$ of mobile phase) to give 20 main fractions. Fr. $5(193 \mathrm{mg})$ was rechromatographed on a silica gel column $(40 \mathrm{~g})$ using EtOAc-hexane $(1.5: 98.5)(1.51)$ to give 5 subfractions. Fr. 5.3 yielded 1 (12 mg). Fr. $9(209 \mathrm{mg})$ was fractionated into 4 subfractions on a siliga gel column $(8 \mathrm{~g})$ using EtOAc-hexane $(8: 92)$ $(300 \mathrm{ml})$ as eluent. Subsequent filtration of fr. 9.3 afforded a mixture of $\mathbf{2}^{2}$ and $\mathbf{3}^{2)}(63 \mathrm{mg})$. Repetitive CC (silica gel, $25 \mathrm{~g}$ ) of fr. 12 (293 mg) using EtOAc-hexane $(80: 20)(1.51)$ as eluent gave 4 subfractions. Fr. 12.3 yielded $4^{3)}(44 \mathrm{mg})$. Fr. $14(211 \mathrm{mg})$ was further purified on a silica gel column $(10 \mathrm{~g})$ eluting with EtOAc-hexane $(80: 20)(300 \mathrm{ml})$ to give 7 subfractions. Compound $\left.\mathbf{5}^{4}\right)(13 \mathrm{mg})$ was isolated from fr. 14.4. Fr. $16(110 \mathrm{mg})$ was rechromatographed on a silica gel column $(7 \mathrm{~g})$ using EtOAc-hexane $(30: 70)(300 \mathrm{ml})$ as eluent to give 6 subfractions. Fr. 16.4 afforded $6^{5}$ $(50 \mathrm{mg})$ while filtration of fr. $18(123 \mathrm{mg})$ furnished $7^{6)}(71 \mathrm{mg})$. The $\mathrm{MeOH}$ extract $(7.37 \mathrm{~g}$ ) was subjected to $\mathrm{CC}$ (silica gel, $150 \mathrm{~g}$ ) eluting with a gradient of $\mathrm{CHCl}_{3}, \mathrm{CHCl}_{3}-\mathrm{MeOH}$ and $\mathrm{MeOH}$ in increasing proportions of the polar solvent (each $200 \mathrm{ml}$ ) to give 9 main fractions. Fr. $7(540 \mathrm{mg}$ ) was further purified on a silica gel column $(30 \mathrm{~g})$ eluting with $\mathrm{MeOH}-\mathrm{CHCl}_{3}$ $(2: 98)(21)$ to give 15 subfractions. Fr. $7.12(136 \mathrm{mg})$ was filtered to give a mixture of $\mathbf{8}^{7)}$ and $\mathbf{9}^{8)}(56 \mathrm{mg})$.

Bornyl Piperate (1): Colorless needles; mp 93-95 ${ }^{\circ} \mathrm{C}$ (hexane); $[\alpha]_{\mathrm{D}}^{27}$ $+7.80^{\circ}\left(c=0.1, \mathrm{CHCl}_{3}\right)$. UV $\lambda_{\max }(\mathrm{MeOH}) \mathrm{nm}: 261,316,353$. IR $(\mathrm{KBr})$ $\mathrm{cm}^{-1}: 3024,2951,1710,1624,1502,1489,1447,1375,1325,1253,1196$, $1175,1139,1037,995,931,880,848,799,754,724$. EI-MS $m / z$ (rel. int.): $354\left(\mathrm{M}^{+}, 30\right), 218$ (38), 202 (14), 201 (100), 173 (18), 143 (11), 137 (27), 115 (13), 81 (26), 69 (11). HR-FAB-MS m/z: 355.1905 (Calcd for $\mathrm{C}_{22} \mathrm{H}_{26} \mathrm{O}_{4}$ $\left.[\mathrm{M}+\mathrm{H}]^{+}: 355.1909\right) .{ }^{1} \mathrm{H}-\mathrm{NMR}\left(\mathrm{CDCl}_{3}\right) \delta: 0.84\left(3 \mathrm{H}, \mathrm{s}, 10-\mathrm{CH}_{3}\right), 0.87(3 \mathrm{H}$, s, 9- $\left.\mathrm{CH}_{3}\right), 0.91\left(3 \mathrm{H}, \mathrm{s}, 8-\mathrm{CH}_{3}\right), 1.01(1 \mathrm{H}, \mathrm{dd}, J=13.1,4.3 \mathrm{~Hz}, \mathrm{H}-3 \alpha), 1.24$ $(1 \mathrm{H}, \mathrm{m}, \mathrm{H}-5 \alpha), 1.33(1 \mathrm{H}, \mathrm{m}, \mathrm{H}-6 \beta), 1.68(1 \mathrm{H}, \mathrm{brt}, J=4.3 \mathrm{~Hz}, \mathrm{H}-4), 1.74$ $(1 \mathrm{H}, \mathrm{m}, \mathrm{H}-5 \beta), 2.00(1 \mathrm{H}, \mathrm{m}, \mathrm{H}-6 \alpha), 2.38(1 \mathrm{H}, \mathrm{m}, \mathrm{H}-3 \beta), 4.96(1 \mathrm{H}, \mathrm{br}$ ddd, $J=13.1,2.6,2.6 \mathrm{~Hz}, \mathrm{H}-2), 5.96\left(1 \mathrm{H}, \mathrm{d}, J=15.3 \mathrm{~Hz}, \mathrm{H}-2^{\prime}\right), 5.97(2 \mathrm{H}, \mathrm{s}, \mathrm{H}-$ $\left.12^{\prime}\right), 6.69\left(1 \mathrm{H}, \mathrm{dd}, J=15.7,10.8 \mathrm{~Hz}, \mathrm{H}-4^{\prime}\right), 6.77\left(1 \mathrm{H}, \mathrm{d}, J=8.2 \mathrm{~Hz}, \mathrm{H}-10^{\prime}\right)$, $6.80\left(1 \mathrm{H}, \mathrm{d}, J=15.7 \mathrm{~Hz}, \mathrm{H}-5^{\prime}\right), 6.90\left(1 \mathrm{H}, \mathrm{dd}, J=8.2,1.5 \mathrm{~Hz}, \mathrm{H}-11^{\prime}\right), 6.98$ $\left(1 \mathrm{H}, \mathrm{d}, J=1.5 \mathrm{~Hz}, \mathrm{H}-7^{\prime}\right), 7.38\left(1 \mathrm{H}, \mathrm{dd}, J=15.3,10.8 \mathrm{~Hz}, \mathrm{H}-3^{\prime}\right) .{ }^{13} \mathrm{C}-\mathrm{NMR}$ $\left(\mathrm{CDCl}_{3}\right) \delta: 13.5$ (C-10), 18.9 (C-8), 19.7 (C-9), 27.2 (C-6), 28.1 (C-5), 36.9 (C-3), 45.1 (C-4), 47.8 (C-1), 48.9 (C-7), 79.7 (C-2), 101.4 (C-12'), 105.9 (C-7'), $108.5\left(\mathrm{C}-10^{\prime}\right), 121.1\left(\mathrm{C}-2^{\prime}\right), 122.8\left(\mathrm{C}-11^{\prime}\right), 124.6\left(\mathrm{C}-4^{\prime}\right), 130.7(\mathrm{C}-$ 6'), 139.9 (C-5'), $144.3\left(\mathrm{C}-3^{\prime}\right), 148.3\left(\mathrm{C}-9^{\prime}\right)^{*}, 148.5\left(\mathrm{C}-8^{\prime}\right)^{*} ; 167.5\left(\mathrm{C}-1^{\prime}\right)$. (Values with an asterisk are interchangeable.)
Crystal Data of (+)-Bornyl Piperate (1): $\mathrm{C}_{22} \mathrm{H}_{26} \mathrm{O}_{4}, \mathrm{MW} 354.45$, Triclinic, $P 1, a=7.3232(4) \AA ̊, b=11.4705(7) \AA, c=23.2520(14) \AA, V=1943.6(2) \AA^{3}$. A total of 7259 unique reflections $\left(6,528\right.$ observed, $\left.\left|\mathrm{F}_{0}\right|>4 \sigma\left|\mathrm{F}_{0}\right|\right)$ were measured at room temperature from a $0.30 \times 0.15 \times 0.05 \mathrm{~mm}^{3}$ colorless crystal using graphite monochromated $\operatorname{MoK} \alpha$ radiation $(\lambda=0.71073 \AA)$ on a Bruker-Nonius kappa CCD diffractometer. With $Z=4$, the asymmetric unit contains four molecules of bornyl piperate with the calculated density of $1.211 \mathrm{~g} \mathrm{~cm}^{-3}$. The crystal structure was solved by direct methods using SIR97 , and then all atoms except hydrogen atoms were refined anisotropically on $\mathrm{F}^{2}$ using SHELXL-97 to give a final $R$-factor of $0.0561\left(R_{\mathrm{w}}=0.1470\right)$ with a data-to-parameter ratio of $7.74: 1$. Atomic coordinates, bond lengths, bond angles, and thermal parameters have been deposited with the Cambridge Crystallographic Data Center, 12 Union Road, Cambridge, CB2 1EZ, ENGLAND (CCDC 214540).

Bioassay Procedure The antimycobacterial activity was assessed against Mycobacterium tuberculosis $\mathrm{H}_{37} \mathrm{Ra}$ strain using the Microplate Alamar Blue Assay (MABA). ${ }^{11)}$ The MIC values of the standard drugs isoniazid and kanamycin sulfate are 0.050 and $2.5 \mu \mathrm{g} / \mathrm{ml}$, respectively.

Acknowledgements This work was supported by the Thailand Research Fund (TRF). The X-ray facility is supported by the Postgraduate Education and Research in Chemistry. We are grateful to Mr. Nitirat Chimnoi, Chulabhorn Research Institute, for recording the mass spectra. Bioassay Research Facility of National Center for Genetic Engineering and Biotechnology (BIOTEC) is gratefully acknowledged for bioactivity tests. We thank Mr. Narong Nantasan, Royal Forest Department, for identifying the plant specimen, Mr. Pairach Sonsuwan and Mr. Werasing Saengwan for assistance.

\section{References}

1) Parmar V. S., Jain S. C., Bisht K. S., Jain R., Taneja P., Jha A., Tyagi O. D., Prasad A. K., Wengel J., Olsen C. E., Boll P. M., Phytochemistry, 46, 597-673 (1997) and references cited therein.

2) Pouchert C. J., Behnke J., "The Aldrich Library of ${ }^{13} \mathrm{C}$ and ${ }^{1} \mathrm{H}$ FT NMR Spectra," 3rd ed., Vol. III, Aldrich Chemical Company, Inc., U.S.A, 1993, pp. 569A and 569B.

3) Likhitwitayawuid K., Ruangrungsi N., Lange G. L., Decicco C. P., Tetrahedron, 43, 3689-3694 (1987).

4) Okogun J. I., Ekong D. E. U., J. Chem. Soc. Perkin Trans. I, 1974, 2195-2198 (1974)

5) Tabuneng W., Bando H., Amiya T., Chem. Pharm. Bull., 31, 35623565 (1983).

6) Pouchert C. J., Behnke J., "The Aldrich Library of ${ }^{13} \mathrm{C}$ and ${ }^{1} \mathrm{H}$ FT NMR Spectra," 3rd ed., Vol. II, Aldrich Chemical Company, Inc., U.S.A, 1993, p. 1379B

7) Ruangrungsi N., Aukkanibutra A., Phadungcharoen T., Lange G. L., Lee M., J. Sci. Soc. Thailand, 13, 57-62 (1987).

8) Alam M. S., Chopra N., Ali M., Niwa M., Phytochemistry, 41, 1197 1200 (1996).

9) Ruangrungsi N., Prathanturarug S., Lange G. S., Organ M. G., Phytochemistry, 31, 2397-2400 (1992) and references cited therein.

10) Setzer W. N., Setzer M. C., Bates R. B., Nakkiew P., Jackes B. R., Chen L., McFerrin M. B., Meehan E. J., Planta Med., 65, 747-749 (1999).

11) Collins L., Franzblau S. G., Antimicrob. Agents Chemother, 41, 1004-1009 (1997). 